\title{
TRABALHO INFORMAL: um problema estrutural básico no entendimento das desigualdades na sociedade brasileira
}

\author{
Márcia da Silva Costa*
}

\begin{abstract}
Este texto resgata o debate teórico-conceitual que envolve o tema da informalidade, em essência, aquele das relações de dominação que favoreceram a acumulação capitalista no país. A partir dos dados da PNAD 2006, também é analisada a distribuição da força de trabalho ocupada. Quem são os informais e como eles se distribuem? Qual o seu perfil de renda e de escolaridade? Os achados corroboram os argumentos analíticos que entendem a informalidade como um problema estrutural básico na sociedade brasileira. Seu crescimento assevera o quadro histórico de desigualdade e pobreza que marcou seu padrão de desenvolvimento. Ainda que a economia volte a crescer, haverá um considerável contingente de trabalhadores que, a menos seja beneficiado com políticas educacionais consistentes, jamais terá a possibilidade de ser incorporado pela economia regulada.

PALAVRAS-CHAVE: trabalho informal, trabalho precário, desigualdade.
\end{abstract}

\section{INTRODUÇÃO}

As instituições do mercado de trabalho no Brasil jamais alcançaram universalmente as massas trabalhadoras e constituíram um conjunto muito pobre de direitos. Desde muito cedo, dos primórdios da formação de um mercado de trabalho livre no país, parcela considerável da população ativa, sobretudo a de cor, jamais conseguiu se incorporar ao mercado de trabalho e, num momento subsequente, já sob os auspícios de uma economia industrial, a regulamentação desse mercado deixou também de fora os trabalhadores rurais e muitas categorias de trabalhadores urbanos. As mudanças institucionais e econômicas da sociedade brasileira, nas quatro décadas de crescimento deslanchadas pela política de substituição de importações, concretizaram-se sem lograr ampliar o padrão de renda-consumo e bem-estar da população e sem qualquer compromisso mais sólido

* Doutora em Sociologia. Professora e Pesquisadora do Departamento e do Programa de Pós-Graduação em Administracão da Universidade Federal da Paraíba.

Centro de Ciências Sociais Aplicadas - Campus I. João Pessoa, PB - Brasil. marciakosta@hotmail.com com uma política de pleno emprego. A constituição de um mercado formal de trabalho, que, no auge do período de crescimento econômico, a década de 70, atingiu apenas 50\% da população economicamente ativa empregada no meio urbano (Pochmann, 2002, 2006a), conviveu pari passu com a expansão de todo um complexo de formas de trabalho informal em pequenas empresas urbanas de fundo de quintal, no campo, e nas inúmeras e precárias formas de trabalho autônomo e doméstico, cujos padrões de contratação e assalariamento passavam ao largo da legislação trabalhista e social e de qualquer possibilidade de representação coletiva.

Essa realidade se agrava sobremaneira na década de 1990 com as mudanças estruturais na economia e nas instituições do mercado de trabalho. A abertura econômica e as privatizações pressionaram o processo de reestruturação produtiva sistêmica, sobretudo no setor secundário, de modo a afetar não apenas o nível do emprego, mas também a sua qualidade, com a flexibilização dos vínculos e dos regimes de trabalho. Com o desemprego em massa, a década de 1990 presenciou a eliminação de cerca de 3,3 milhões de postos de tra- 
balho formais na economia (Mattoso, 1999), coadunada às diversas experiências de subcontratação (crescimento das pequenas firmas com baixo nível de capitalização, trabalho autônomo, cooperativas de fachada), que foram fatores decisivos no fenômeno da desestruturação do mercado de trabalho e da ampliação da informalidade no país.

A queda no nível do assalariamento formal entre 1980, período de arrefecimento do desempenho econômico que pressionou o abandono da política de substituição de importações, e o ano 2000 pode ser visualizada na proporção das ocupações abertas no período: $57 \%$ delas não tinham carteira de trabalho assinada. No mesmo período, a taxa de precarização do mercado de trabalho, considerada como a soma das ocupações por conta própria, dos sem remuneração e do total dos desempregados, cresceu de $34,1 \%$ para $40,4 \%$ da PEA (Pochmann, 2002). Essa realidade é ainda mais assombrosa se consideramos o desemprego oculto pelo desalento. Entre 1992 e 2001, há um crescimento explosivo de $70 \%$ no número da desocupação oculta pelo desalento, sendo esse um fenômeno que atinge mais intensamente os mais jovens e as famílias da massa popular urbana formada pela baixa classe média, operários e demais trabalhadores populares e empregados domésticos (Quadros, 2003).

No âmbito institucional, com os sindicatos na retranca, avançaram as iniciativas de flexibilização dos direitos do trabalho: o medo do desemprego passou a coagir muito mais brutalmente a capacidade organizativa dos trabalhadores. Assim, a participação dos empregados formais caiu de $53 \%$, em 1991, para 45\%, em 2000. Em contrapartida, o grau de informalidade que era de $36,6 \%$ em 1986, aumentou para 37,6\%, em 1990, e para 50,8\%, em 2000 (Sabadini; Nakatani, 2002; Cacciamali, 2000. Nãoé mera casualidade, portanto, que os arranjos informais de emprego se ampliaram e se diversificaram com as experiências de desverticalização e enxugamento da típica organização fordista do trabalho através de iniciativas diversas de subcontratação e das demissões em massa nas grandes empresas.

Para onde, então, se deslocaram os desem- pregados e o contingente do crescimento da PEA para os quais a economia não gerou novos postos de trabalho? Para a grande maioria dos trabalhadores demitidos, o desemprego significou a exclusão do mundo dos empregos registrados e legalmente protegidos (Cardoso et al, 2006; Chahad, 2006) e, para muitos dos novos entrantes, sobretudo para os jovens pouco instruídos, a informalidade é o horizonte que se abre (Frigotto, 2004; Ramos et al, 2005; Hasenbalg, 2003; Sanzone, 2003). A população passou predominantemente a encontrar sua fonte de renda no mercado de trabalho informal, com suas mais variadas formas de trabalho autônomo, ambulante, temporário, irregular, precário. A imagem mais fidedigna do significado desses indicadores é aquela do crescimento no período do número de trabalhadores nas ruas dos grandes centros urbanos vendendo de tudo: roupas, alimentos, produtos importados da China, uma atividade acompanhada por uma economia, também subterrânea, composta de redes de pequenas e médias firmas clandestinas que intermediam trabalho barato, muitas vezes em condições quase escravas, para firmas capitalistas de grande porte. Da mesma maneira, foi notório o crescimento do número de antigas atividades jamais reconhecidas como trabalho regular ou regulamentado: guardadores de carro nas ruas, catadores de lixo, outdoors humanos ambulantes, carregadores de feira, trabalhadores domésticos casuais, etc. Essa nova informalidade urbana, que se expande em modalidades diversas de atividades, contribuindo para uma heterogeneidade ainda maior do mercado de trabalho, tem como marca a precariedade das condições de trabalho e de vida, a negação dos princípios mais elementares de cidadania, a perpétua reprodução da pobreza e das desigualdades sociais.

Este texto é produto preliminar de uma pesquisa mais ampla, de natureza qualitativa, cujo objetivo é conhecer as condições de trabalho e de vida dos trabalhadores de rua da capital de um estado do nordeste brasileiro. Nele, procuro resgatar o debate teórico-conceitual que envolve o tema da informalidade. Esse debate, hoje mais controverso, ressalta a própria confusão conceitual que o 
termo evoca, devido à complexidade dos arranjos produtivos que se manifestam à base de um imbricamento muito maior entre o formal e o informal. Essa discussão é tratada nas duas seções do artigo que se seguem a esta introdução. Logo em seguida, e como forma de operacionalizar empiricamente o conceito, é analisada, a partir dos dados da PNAD 2006, a distribuição da força de trabalho ocupada no país, segundo sua forma de inserção na atividade produtiva. Quem são os informais e como eles se distribuem no agregado dos trabalhadores ocupados? Qual o seu perfil de renda e de escolaridade? Os achados de pesquisa ali trabalhados corroboram os argumentos analíticos que entendem a informalidade como um problema estrutural básico na sociedade brasileira. Seu crescimento na década de 90, a reboque das transformações econômicas e institucionais, assevera o quadro de desigualdade e pobreza que historicamente marcou o desenvolvimento do país. Ainda que a economia retome o ritmo de crescimento, haverá um considerável contingente de trabalhadores que, a menos seja beneficiado com políticas educacionais, jamais será incorporado pela economia regulada. Mais que isso, sem reformas estruturais profundas, sobretudo no regime de relações de trabalho e na estrutura fundiária, a retomada do crescimento e uma possível ampliação do emprego regulado, como vem sendo timidamente registrado nos últimos 5 anos, muito dificilmente ou apenas de forma bastante limitada podem contribuir para uma reversão da enorme informalidade e do quadro de desigualdades econômicas e sociais do país.

\section{O DEBATE DOMINANTE SOBRE A INFORMA- LIDADE NOS ANOS DE 1960-1970}

A informalidade foi inicialmente discutida nas décadas de 1960 e 1970, no bojo das interpretações da realidade dos países subdesenvolvidos da América Latina e da África, cujos projetos de modernização pela via da industrialização deixavam de incorporar vastos segmentos produtivos e do mercado de trabalho ao ordenamento institucional de uma economia tipicamente capitalista e regulada. O debate sobre a informalidade surge dessa noção de subdesenvolvimento, para explicar o fenômeno da não-inserção dos estratos menos favorecidos da população no processo produtivo em contextos nos quais o assalariamento era pouco generalizado (Silva, 2003). Na época, ele se dividia em duas correntes centrais: uma de base estruturalista e outra de extração marxista.

A corrente estruturalista era representada pelas reflexões da chamada Teoria da Modernização, segundo a qual o subdesenvolvimento seria decorrência de uma desvantagem no valor relativo das trocas econômicas entre o centro desenvolvido e a periferia, sobretudo em relação à economia externa. Os países da América Latina, cujos modelos de industrialização foram centrados na política de substituição de importações, contavam com um nível de acumulação muito baixo para fazer frente aos requisitos da moderna produção industrial. Daí a expansão de firmas e empreendimentos modernos, tipicamente capitalistas, concomitante à proliferação e recriação das formas tradicionais de produção e de relações de trabalho. Essa corrente, que tinha como principais expoentes os economistas da CEPAL, ${ }^{1}$ concebia a estrutura econômica da região de uma perspectiva dual, marcada pela presença de um setor de subsistência ou informal, caracterizado pela baixa densidade de capital, pelo precário nível técnico de produção e pela baixa produtividade, convivendo com um setor moderno, de avançado padrão tecnológico, economicamente mais capitalizado e dinâmico.

Essa interpretação analítica do funcionamento da economia a partir de uma lógica polarizada da coexistência, no seio de uma mesma sociedade, do arcaico e do avançado, porém de forma desarticulada, vai dar corpo à chamada Teoria $d a$ Marginalidade. Ela explica o problema da integração e não-integração através da idéia de um desajuste ou uma inadequação (de indivíduos, regióes, atividades econômicas) a um "padrão normal, tido

${ }^{1}$ Comissão Econômica para a América Latina e Caribe. Para uma breve apreciação das principais contribuições dos teóricos da Cepal ao pensamento econômico latinoamericano ver, por exemplo, Furtado (1985, 1998). 
como inerente e próprio de uma caracterização genérica e abrangente de cultura industrial" (Kovarick, 1975, p.47). O excedente de mão de obra, predominantemente advinda das áreas rurais, que não conseguia inserir-se na esfera da produção capitalista organizada e hegemônica, constituía um segmento à parte, não-funcional ao padrão de acumulação subjacente ao modelo de industrialização, portanto, à margem do sistema. Sua incorporação dependeria das adequações, sobretudo no âmbito das qualificações e das concepções culturais, aos requisitos de uma sociedade industrial.

Nos prognósticos desses teóricos, o problema do subdesenvolvimento seria paulatinamente resolvido à medida que a expansão monopolista das firmas capitalistas (o padrão normal) incorporasse o contingente de indivíduos desajustados, excluídos do processo de modernização. O pressuposto subjacente era o das etapas históricas distintas, no sentido de que os países em desenvolvimento deveriam percorrer a trilha do progresso já percorrida pelos países desenvolvidos. Sob essa crença, o setor atrasado tenderia a diminuir ou desaparecer, alçado, como subproduto, pela dinâmica de crescimento do setor moderno e pela política do pleno emprego. Notadamente, essa era uma visão eurocentrada, segundo a qual o arcaico ou o tradicional é pensado como atravancador do desenvolvimento, e não como parte integrante da cultura e da identidade nacional, um desenvolvimento nos moldes do progresso idealizado pela cultura estrangeira (Kovarick, 1975; Cacciamali, 1983). Com base nessa concepção, a aposta na expansão das firmas monopolistas deixava de fora dos planos de governo ou de sociedade o fomento, em moldes mais adequados à realidade e aos interesses autóctones, de atividades produtivas não-capitalistas, mas importantes para a geração de renda e para a sobrevivência de muitos indivíduos. O modelo de desenvolvimento eurocentrado pressupunha a mercantilização de todas as esferas da vida econômica e considerava como arcaicas, subdesenvolvidas e periféricas todas as formas de trabalho e consumo não-mercantis (Silva, 2003).

Essa visão dicotômica e funcionalista do pro- blema do subdesenvolvimento na América Latina, em cujo vórtice está parcela significativa da população excluída da distribuição da riqueza, foi alvo de crítica da outra grande corrente interpretativa, de base marxista. Essa corrente pensava o problema da não-integração da perspectiva das contradições do próprio modelo de acumulação capitalista consolidado sob a égide da industrialização: da perspectiva das contradições da estrutura de classe e das relações de poder. Esse corpo teórico alternativo, sistematizado num conjunto de idéias construídas em torno da chamada Teoria da Dependência, concebia o subdesenvolvimento não como um estágio anterior do desenvolvimento, mas como produto de uma inserção subordinada e dependente dos países da região no sistema capitalista mundial. Uma subordinação que articula interesses de classe ou grupos específicos internos com os interesses de classe ou grupos do capital estrangeiro. Por essa lógica, o desenvolvimentismo da política de substituição de importações foi capaz de gerar excedente econômico absorvido pelo exterior e pelas elites nacionais, mas que não foi absorvido internamente pelas massas da população (Oliveira, 2003; Kovarick, 1975; Silva, 2003; Theodoro, 2004).

A crítica basilar dessa corrente às teses da modernização como marginalidade, e que vai buscar seu fundamento na lei geral da acumulação capitalista de Marx, sustenta que o problema da marginalidade e da informalidade, nas economias subdesenvolvidas, decorre não de uma condição de inadequação de parte do sistema (o arcaico) a seu padrão normal de funcionamento (o moderno); ao contrário, é resultado de um modo de acumulação capitalista, estruturado sob uma lógica de dominação das relações de produção, portanto de classe, que gera seu próprio excedente de trabalho: um exército industrial de reserva que vai buscar seu meio de sobrevivência fora do domínio das relações capitalistas modernas e que é, sim, funcional e rentável àquele padrão de acumulação, posto que é fator de barateamento e disciplinamento da força de trabalho. Nas palavras de Francisco de Oliveira (2003, p.32), na crítica mais visceral ao mainstream do pensamento econômico da época: 
... a oposição na maioria dos casos é tão somente formal: de fato, o processo real mostra uma simbiose e uma organicidade, uma unidade de contrários, em que o chamado moderno cresce e se alimenta da existência do atrasado [...] o subdesenvolvimento é uma produção da expansão do capitalismo. (grifos do autor)

Por outro lado, a crença dos estruturalistas na capacidade de incorporação da força de trabalho marginalizada nas atividades propriamente capitalistas, à medida que o capitalismo expandia seu domínio oligopolista para todas as esferas da produção, encontrava um limite na própria capacidade de o sistema absorver força de trabalho, por conta mesmo do estágio de evolução das forças produtivas. A análise comparativa com a trajetória de desenvolvimento dos países do norte leva ao argumento de que a industrialização tardia da América Latina se deu sob uma base técnica avançada, portanto, capital-intensiva, poupadora de trabalho, incapaz de operar, como o fez nas primeiras formas históricas de desenvolvimento da indústria (o sistema manufatureiro e a grande indústria), no sentido de universalizar o trabalho assalariado (Kovarick, 1975; Oliveira, 2003).

Nesse sentido, o debate sobre a informalidade nos países subdesenvolvidos nasce da análise do próprio modelo de desenvolvimento na região, este centrado numa industrialização capital-intensiva, que gera pouco emprego e é incapaz de absorver força de trabalho coadunada com o padrão de crescimento demográfico. A rápida urbanização experimentada nas décadas de 60 e 70 impulsionou o fluxo migratório de indivíduos que não foram absorvidos pela atividade capitalista organizada, onde prevalece o trabalho regulamentado e formal. Ela se expandiu, tomando o espaço das atividades tradicionais, mas foi incapaz de gerar empregos na mesma proporção dos que destruiu ou dos que a sociedade necessitava. O caminho naturalmente seguido foi o da ampliação e mesmo o da criação de novas modalidades de trabalho informal ou o desemprego. É esse excedente de mão de obra, "que se auto-emprega para sobreviver" e vai dar origem ao setor informal, numa lógica que, como escre- veu Cacciamali, bebendo da fonte das teses da organicidade, "se insere e se amolda aos movimentos da produção capitalista, modificando sua composição e seu papel à medida que se modifica e se expande aquela produção” (1983, p.27).

Esse movimento de expansão do trabalho informal teve impacto decisivo no setor de serviços, tradicionalmente mais passível, em determinados ramos, para a proliferação das atividades informais. Ampliaram-se, assim, os ramos e atividades dos serviços de: apoio à produção e à comercialização industrial (armazéns, ambulantes, as diversas atividades de reparação de carros, eletrodomésticos, representantes autônomos, etc.), aqueles destinados às unidades de consumo das famílias, aqui incluído o emprego doméstico, e aos indivíduos; os serviços sociais; motoristas de táxi, caminhoneiros, e inúmeros outros trabalhadores por conta própria.

Levando em conta o padrão de industrialização brasileiro, notadamente as formas institucionais com as quais esse padrão se consolida no campo das relações de trabalho, o trabalho informal pode ser conceituado como aquele nãoregulamentado pelo ordenamento legal do trabalho no país, sobre o qual, inclusive, a sociedade construiu sua política de seguridade social. E, nesse último aspecto, o fenômeno da não-integração foi ainda mais pernicioso: além de fraca, a intervenção do Estado na criação de políticas e mecanismos de proteção social atingia apenas os trabalhadores formalmente reconhecidos pela relação salarial, um tipo de incorporação social a que Santos (1979) chamou de cidadania regulada, aquela adquirida unicamente pelos indivíduos enquadrados na estrutura ocupacional definida e reconhecida pelo Ministério do Trabalho. Essa base institucional alimentou todo um conjunto de valores na sociedade brasileira que associava tudo o que não constituísse trabalho formal (desemprego, formas de trabalho precário e instável) à marginalidade.

No entanto, o entendimento da lógica da integração ou não-integração ao padrão que aquele ordenamento estabelece, e de todas as suas 
consequências sociais (e culturais) no que concerne ao problema da pobreza e da distribuição de renda, só pode ser alcançado quando consideramos as características histórico-estruturais do desenvolvimento do capitalismo no país. Colocando de outra forma, como se estruturaram as relações de dominação? Lembrando do que nos ensinou Darcy Ribeiro (2006, p.23), as evidências das contradições de classe mais básicas e enraizadas na nossa sociedade se encontram "no sistema institucional, notadamente a propriedade fundiária e o regime de trabalho - no âmbito do qual o povo brasileiro surgiu e cresceu constrangido e deformado". É para uma breve reflexão sobre essas contradições estruturais que me volto agora, mais especificamente para o âmbito do regime de trabalho.

É impossível entender o processo recente de ampliação dos regimes de emprego informais e precários no Brasil sem caracterizarmos, ainda que brevemente, a origem e as características da institucionalização do mercado de trabalho no país. $^{2}$ A lei nacional, a Consolidação das Leis do Trabalho (CLT), promulgada em 1943, definiu os direitos individuais básicos de proteção ao trabalhador e a estrutura da representação de classe ainda hoje vigentes no país. Resultado das pressões do movimento trabalhista de desde finais do Século XIX, a CLT respondia à necessidade de incorporação política dos trabalhadores urbanos da indústria nascente que, em face de seu poder de organização, constituíam potencial de ameaça aos planos de desenvolvimento do Estado. Os sindicatos foram reconhecidos, mas o Estado tomou para si o completo controle administrativo e político de suas atividades. A contrapartida veio pela imposição legal às empresas de reivindicações trabalhistas elementares, objeto de décadas de luta. ${ }^{3}$ Assim, no Brasil, o Estado assumiu o papel central na regulação e mediação dos interesses de empregados e empregadores. A barganha coletiva não teve

${ }^{2}$ As reflexões deste e dos dois parágrafos abaixo são mais profundamente desenvolvidas em Costa (2005, 2006).

${ }^{3}$ A CLT consolidava um conjunto de leis arbitrando o uso do trabalho na indústria nascente e restringindo a liberdade de contratação das empresas: limitação da jornada de trabalho em 48 horas, proibição do trabalho de menores de 14 anos, regulamentação do trabalho femini- a importância política e econômica alcançada nos países democráticos. Não vingou, entre nós, a noção de conciliação política baseada na negociação autônoma de interesses entre grupos organizados.

Por outro lado, o marco legal incorporava os trabalhadores de forma limitada por duas frentes: em primeiro lugar, porque a legislação de direitos mínimos e de sindicalização deixava de fora a grande massa dos trabalhadores rurais que, à época, constituíam absoluta maioria da força de trabalho no país, e os servidores públicos; ${ }^{4} \mathrm{em}$ segundo, porque grande parcela dos trabalhadores urbanos não gozou do status do emprego regulamentado e sobre o qual o Estado definia as políticas de seguridade social. Portanto, também não vingou entre nós a noção de uma política macroeconômica pautada na geração de demanda agregada advinda dos esforços para garantir o quase pleno emprego.

Com sindicatos controlados e a maioria dos trabalhadores não auferindo direitos, o crescimento econômico realizou-se sem uma associação direta com o aumento do padrão de renda-consumo e bem-estar da população e sem qualquer compromisso mais sólido com uma política de pleno emprego (pautada na estabilidade). Ao contrário, como originalmente argumentou Francisco de Oliveira, certo desemprego estrutural foi benéfico ao tipo de acumulação escolhido e funcional à geração de um mercado de trabalho de baixíssima remuneração, espaço de proliferação das inúmeras formas de trabalho subterrâneo e precário. Em outras palavras, a massa trabalhadora não participou do processo de crescimento e da acumulação de capitais, de maneira que não houve efetiva redistribuição dos ganhos de produtividade da economia. Adicione-

no, remuneração obrigatória da hora extra, descanso de final de semana e férias remunerados, condições de salubridade e proteção contra acidentes de trabalho, entre outros.

${ }^{4}$ Até os anos 70, quando se acentuaram os conflitos no campo, os trabalhadores rurais ficaram submetidos às leis do mercado e da milícia dos seus patrões, sem a cobertura de direitos legais. Essa foi uma forma de compensar a perda do poder político-econômico das oligarquias primário-exportadoras. Da mesma maneira que os servidores do serviço público ficaram submetidos aos vieses da burocracia patrimonialista e clientelista do Estado. Um estatuto de direitos e deveres próprio foi apenas instituído em 1990, mas garantindo a soberania do Estado na definição dos termos do trabalho. 
se a isso a inexistência de um sistema amplo de regulação coletiva que tivesse por base a garantia de direitos cidadãos (campo de atuação de um Estado de Bem Estar responsável pela universalização de direitos sociais básicos) e temos um quadro de forte heterogeneidade estrutural das condições de trabalho e emprego, restringindo o poder de abrangência da legislação trabalhista e de seguridade social. Essa realidadeé profundamente agravada nos anos de 1990, com o emprego informal superando as estatísticas do emprego formal.

A incorporação limitada dos trabalhadores ao projeto político de expansão do capitalismo no país respondia à necessidade de as elites agrárias e industriais criarem um exército industrial de reser$v a$, funcional à disciplina da força de trabalho e à manutenção de seu baixo padrão de remuneração. Esse exército foi alimentado, principalmente, pela população que fluía do campo para as cidades. Sem mudanças profundas que reconfigurassem a estrutura fundiária altamente concentradora, e limitando ou impedindo o conflito de classe, o Estado favorecia a acumulação capitalista à custa da ampliação das desigualdades de classe e de um crescente processo de concentração de renda. É importante ressaltar, nesse aspecto, que o debate sobre a informalidade, a despeito de sua heterogeneidade, sobretudo nas formas de rendimento, foi sempre associado ao tema da pobreza, dado que parcela significativa de seu universo provém das camadas pobres da população. O problema maior, então, se encontra, como atentaram Portes e Castells (1989), não necessariamente na informalidade em si, que é uma forma específica de relações de produção, mas na forma como a sociedade distribui sua riqueza.

Se a expansão e modernização industrial brasileira do pós-1930, sobretudo a dos anos 1950 e 1960, com a vinda das multinacionais, permitiu uma elevada mobilidade social, ela permitiu também, e contraditoriamente, uma enorme diferenciação das ocupações e dos salários, impedindo que se mudasse a desigualdade da estrutura de classe no país. Empregos e salários tornaram-se variáveis extremamente flexíveis de ajuste econômico, excluindo parcela considerável da população dos benefícios do crescimento e ampliando os bolsões de pobreza.Énesse sentido que, comparativamente à realidade da institucionalização do mercado de trabalho e das políticas de bem estar dos países desenvolvidos, o Brasil jamais conseguiu criar uma classe média ampla com poder de consumo (Oliveira, 2003; Hasembalg, 2003; Costa, 2005; Mattoso, 1996). ${ }^{5}$

A acumulação capitalista no Brasil (o crescimento do setor moderno da economia) muito se beneficiou das formas arcaicas de relações de trabalho no campo (o setor atrasado). De um lado, a mecanização-capitalização da agricultura aconteceu com o domínio latifundiário das terras produtivas, expulsando-se ou proletarizando-se camponeses, muitas vezes, sob regimes de trabalho semiescravo. De outro, é na base da superexploração de trabalho barato que a produção agrícola, ainda hoje sustentáculo das divisas cambiais do país, vai subsidiar a industrialização urbana (fortemente dependente de endividamento externo) e o baixo custo de reprodução da força de trabalho. As desigualdades desse padrão de crescimento, no entanto, foram marcadamente regionais, com o dinamismo econômico e a formalização dos empregos, embora jamais de forma universal, mais acentuados no centro-sul do país. O norte e o nordeste se destacam com a predominância das formas mais precárias e desprotegidas de relações de trabalho: trabalho não-registrado, trabalho por conta própria, serviços domésticos, mão de obra familiar sem remuneração, boias frias e elevada desocupação. Énessas regiões, e mais especificamente no Nordeste brasileiro, que a informalidade e a insegurança que ela representa mais se associam à condição de pobreza

${ }^{5}$ Essa mobilidade social foi vivida, sobretudo, pelos trabalhadores do campo, que foram alçados à condição de trabalhadores manuais semi ou não-qualificados nos centros urbanos. A esse respeito, Francisco de Oliveira (2003) argumenta que a intensa mobilidade do período obscurece o fato de que os salários (um dos caminhos centrais da distribuição de renda) tomavam como base o custo de subsistência do trabalhador, não os ganhos de produtividade da moderna indústria, por onde se poderia realizar uma efetiva redistribuição de renda. Para uma análise da imutabilidade da estrutura de classe e do padrão de desigualdade, a despeito do crescimento acelerado da economia no chamado período do milagre econômico e das reformas pós-redemocratização do país ver, por exemplo, Costa (2003); Henriques (2000). 
e indigência da população. ${ }^{6}$ Essa realidade, portanto, não pode ser entendida fora da perspectiva que contempla a enorme concentração fundiária e um caldo de cultura fortemente autoritário, herança de uma economia colonial agroexportadora centrada no trabalho escravo.

Assim, ainda que a industrialização induzida pela intervenção planejada do Estado através das agências de desenvolvimento regional (SUDENE e SUDAM), nas décadas de 1960 e 1970, tenha fomentado o processo de urbanização e a ampliação dos empregos formais, sobretudo nas regiões metropolitanas e nas cidades de médio porte, essa expansão é contra-arrestada por pelo menos três fenômenos estruturais fundamentais: 1) pelas incessantes ondas migratórias de camponeses expropriados de seus meios de produção, expulsos da terra pela expansão da mecanização e industrialização da agricultura latifundiária (o moderno agrobusiness) e pela seca; 2) pelo baixo dinamismo econômico da própria industrialização da região que, ao fomentar a instalação de subsidiárias (fornecedoras de matéria prima e insumos produzidos com mão de obra barata) das empresas sediadas no sudeste-sul do país, permitiu, na realidade, uma maior concentração da acumulação capitalista, cabendo ao Nordeste uma posição subordinada e dependente em relação à centralização do poder político-econômico nas regiões mais desenvolvidas (Oliveira, 1977, p.3). Esse baixo dinamismo econômico, combinado à velha cultura política coronelista-patrimonialista e a um crescente exército industrial de reserva vindo do campo, irá limitar ou diretamente reprimir as iniciativas de organização coletiva do trabalho, caminho mais legítimo pelo qual seria possível expandir os direitos trabalhistas e cidadãos.

A massa de indivíduos vinda do campo, expulsa pela falta de terra para produzir e pela ausência do Estado, não apenas na questão dos

${ }^{6}$ Levantamento da pesquisa Mapa do Fim da Fome da Fundação Getúlio Vargas (Jornal do Brasil, 10/07/2001) mostra que $29,3 \%$ da população brasileira vivem abaixo da linha da indigência, recebendo uma média mensal percapita inferior a R $\$ 80,00$ ou cerca de US\$33,00/mês. Essa proporção salta para $50 \%$ da população nos estados do nordeste brasileiro, nos dando uma mostra das disparidades socioeconômicas regionais do país. incentivos técnicos e econômicos, mas, sobretudo, numa de suas funções sociais mais básicas, essa massa vem para as cidades e não encontra o emprego condigno e as condições de infraestrutura urbana adequadas. Poderíamos citar pelo menos três consequências imediatas dessas transformações: 1) o crescimento desordenado das favelas nos centros urbanos; 2) a inserção desses indivíduos no mercado de trabalho de forma precária, irregular (mesmo no mercado formal, basta pensarmos o caso dos trabalhadores da construção civil) e informal; e 3) o acirramento da competição entre os próprios trabalhadores, de modo a reiterar a condição de barateamento e disciplinamento da força de trabalho urbana. ${ }^{7}$

Esse é o pano de fundo histórico-estrutural a subsidiar a construção de uma noção de informalidade que mais fielmente explica as contradições de classe no país e a origem mesma da informalidade; uma informalidade muitas vezes imiscuída nas redes da criminalidade. Ela se agrava sobremaneira nos últimos vinte anos, com as transformações da chamada acumulaçãoflexível.

\section{ANOVA INFORMALIDADE}

As mudanças econômicas e institucionais do capitalismo após os anos 80, centradas nas ideias da empresa enxuta e da flexibilização, com a desregulamentação dos mercados de trabalho, fizeram mudar também o foco analítico do problema da informalidade, tornando muito mais complexa e confusa a tarefa de interpretação e definição conceitual para a questão. Luiz Machado da Silva (2003) argumenta sobre a inespecificidade e sobre a banalização da noção de informalidade nesse novo contexto. Segundo sua análise, entre os anos 1950 e 1970, o debate teórico, ainda que acalorado por perspectivas em conflito, era apoia-

\footnotetext{
${ }^{7}$ A lista das mazelas sociais do padrão de desenvolvimento da sociedade brasileira é infindável e autorreproduzível: ao lado do desemprego e da ausência ou insuficiência da ação do estado nas áreas mais elementares (saúde, educação, habitação, infraestrutura urbana de saneamento, seguro desemprego, etc.) crescem os bolsões de pobreza e a violência e criminalidade urbana.
} 
do num conjunto de pressupostos compartilhados em torno da questão: a indústria como polo dinâmico da economia; um padrão específico de regulação das relações de trabalho; a expectativa de uma eventual universalização dos direitos pertinentes àquele padrão de regulação (a ampliação do assalariamento); e um ideal como meta de pleno emprego.

A partir dos anos 80, esse debate é transformado como reflexo das transformações do capitalismo e do crescimento do desemprego. As mudanças analíticas do problema da informalidade passam a se dar: 1) em torno da perda da centralidade e do dinamismo do setor secundário, ao menos no tocante à sua capacidade de gerar emprego, produto de uma reestruturação produtiva que abala os próprios fundamentos da relação salarial, cabendo destacar as experiências da subcontratação; e 2) em torno da crescente importância do setor terciário na absorção da força de trabalho, este tradicionalmente menos regulado e mais precário. Ainda segundo Silva, nesse novo contexto, disseminam-se as análises preocupadas em entender o processo de fragmentação e das diferenciações nas formas e conteúdos do trabalho e seus efeitos sobre a estratificação social. No entanto, o tema da integração e não-integração, ou da inserção dos trabalhadores no processo de produção e distribuição da riqueza, continua como pano de fundo, ainda que essa questão-chave da teoria da marginalidade tenha sua versão contemporânea nas expressões exclusão social, vulnerabilidade, precariedade.

Por outro lado, se, no debate anterior, a informalidade era associada à periferia do capitalismo, ao problema do subdesenvolvimento, à perspectiva de integração social pelo padrão de assalariamento, aparecendo como forma atípica, como condição transitória, no debate dos anos 80 , na esteira das transformações de um capitalismo globalizado, essa informalidade se generaliza e se apresenta também como um problema dos países desenvolvidos, e o próprio padrão de assalariamento passa a ser questionado através da pura desregulamentação e (ou) da regulamentação em patamar inferior. É nesse sentido que o debate ori- ginal sobre as formas de inserção das massas desfavorecidas no processo produtivo e sobre a lógica de dominação a elas subjacentes vai cedendo lugar a um discurso economicista e determinista sobre os necessários ajustes para que o país alcance os parâmetros econômicos da competitividade internacional, a despeito dos elevados custos sociais do novo receituário de política econômica. Numa sociedade como a brasileira, que jamais conseguiu expandir o assalariamento, a retórica se concentrava no anacronismo e na disfuncionalidade da legislação trabalhista, ainda proveniente da era Vargas. Para muitos analistas do emprego, para os empresários, para o governo e para algumas lideranças sindicais, aquela legislação não acompanhava o passo das transformações econômicas e produtivas necessárias ao ajuste competitivo do país. O caminho da "modernidade" passava pelas agressivas reformas no âmbito das privatizações, da previdência, da desregulamentação dos mercados produtivos e de trabalho. Nesse último, a saída, então, era flexibilizar os estatutos que, segundo eles, oneravam o custo do trabalho e inviabilizavam a geração de empregos. Esse discurso legitimava uma tendência, que vinha se acentuando, de informalização da própria economia.

Assim, ganhava muito mais relevância o aspecto jurídico-institucional que permeia a noção de informalidade, sendo ela normalmente definida como um contraponto da formalidade, aquela das relações de trabalho reguladas pelo padrão de assalariamento típico da empresa capitalista. $\mathrm{O}$ foco da questão se deslocava, então, da aposta político-ideológica num projeto de universalização de direitos pela via do compromisso com o emprego regulado e de longo prazo, para aquela de uma sociedade do emprego possível, não como meta social, flexível, desvinculado, temporário e de baixo custo. Ainda recorrendo às reflexões de Silva (2003), essa mudança remetia ao conteúdo propriamente político do conflito social, o que quer dizer, na linha do que estou argumentando, que perdia força o embate político em torno das reformas estruturais efetivamente voltadas para os interesses das massas trabalhadoras; em contrapartida, 
ganhava força o discurso da desregulamentação.

Em termos empíricos, no Brasil, o movimento de consolidação da economia organizada e do trabalho formal sofre significativa inflexão na década de 1980, asseverando as desigualdades estruturais. Seu retraimento será ainda mais acentuado, e presenciamos mesmo a sua reversão a partir da década de 1990, como decorrência dos ajustes econômicos "pró-mercado" implementados pelos governos Collor de Melo e Fernando Henrique Cardoso, em especial a abertura econômica e as privatizações de empresas estatais. A reestruturação produtiva, então deslanchada pelas empresas, redundou num fenômeno de demissão em massa jamais vivido na história da industrialização do país. O desenvolvimento e a incorporação de equipamentos automatizados e de novos métodos de organização e gestão do trabalho aceleraram o processo de racionalização assentado na desverticalização e na emergência de sistemas de subcontratação de produtos e serviços. A terceirização, nas grandes empresas, sob a lógica de uma nova divisão internacional do trabalho, organizada com base numa profusão de pequenas firmas, muitas delas trabalhando em redes, constituiu-se numa das estratégias centrais de redução dos custos do trabalho que, de uma perspectiva agregada, traduziu-se na substituição de empregos regulares e com certo padrão de conquistas por empregos precários, temporários, muitas vezes não-regulamentados (Mattoso, 1997; Deddeca, 1997; Boito Jr, 1999; Pochmann, 2002).

Com a quebra das fronteiras advinda das facilidades da tecnologia da informação e das desregulamentações, as empresas têm muito mais mobilidade para buscar recursos e trabalho onde eles se mostrem economicamente mais vantajosos. Tornam-se muito mais complexas as relações e articulações entre grandes firmas e pequenos negócios espalhados pelo mundo e, entre elas, e os trabalhadores por conta própria, os da produção doméstica, os cooperados, muitas vezes articulados por puros intermediadores de força de trabalho, sob condições que reeditam relações pré-capitalistas de produção. Castells (2001, p.285-286) nos fala de uma transformação fundamental na era da socieda- de informacional: a individualização do trabalho. Essa individualização possibilita a descentralização das tarefas para qualquer lugar e sua coordenação através de redes interativas de comunicação em tempo real. Tal possibilidade técnica permite que as empresas ponham em marcha estratégias de subcontratação, consultoria, redução do quadro funcional e produção sob encomenda, utilizando regimes de emprego flexíveis, autônomos, informais, configurando arranjos produtivos que obscurecem ainda mais as fronteiras entre o formal e o informal.

As consequências sociais das transformações organizacionais e tecnológicas da típica empresa capitalista foram diretamente sentidas no aumento do desemprego, com impactos decisivos na expansão e na criação de novas modalidades de trabalho informal, na redução ou retirada das contrapartidas sociais dos empregos ofertados e na ampliação da heterogeneidade das condições de trabalho, de renda e de vida da população. Todavia, seu impacto mais negativo se deu sobre o poder de organização e ação coletiva do trabalho em todas as esferas: na barganha econômica, na organização social e na influência política (Silva, 2003; Portes et al, 1989; Castells, 2001; Ramalho; Santana, 2003; Laranjeira, 1998; Antunes, 2000).

Ademais, os novos fenômenos da organização da produção e do trabalho nos chamam a atenção para um problema social global de muito maior alcance. Como nos lembra Castel (1998), refletindo sobre a realidade francesa, mas que muito bem traduz o comportamento das empresas em todas as partes: tão problemático quanto o desemprego é a degradação do paradigma do emprego tradicional, base, inclusive, de sustentação dos programas de seguridade social do Estado. Mais que isso, e esse é um argumento também encontrado em Silva $(2003,1996)$ : as consequências das transformações no mundo do trabalho são sentidas não apenas no campo da produção e distribuição da riqueza (ou da pobreza, como ironiza esse autor), mas elas são mais problemáticas por seus efeitos destrutivos no campo de um ideal (e efetivo mecanismo) de socialização em que o trabalho (nos moldes do paradigma do emprego tradi- 
cional) aparece como principal elemento de integração social, o campo onde foram construídas as identidades coletivas que direcionaram o próprio conflito de classe e no qual os indivíduos encontram um sentido de pertencimento. Castel atenta para a perda da função integradora da empresa, a grande unidade da economia. Se hoje ela ostenta o grande símbolo da competição e do sucesso, ostenta também o papel de uma máquina de vulnerabilizar e de excluir: o emprego, e o emprego com direitos e benefícios conquistados pela barganha política, estão deixando de ser a referência.

O ponto-chave dessa questão, e certamente Castel e Silva encontraram subsídio analítico nas reflexões originais de Karl Polanyi (1980), é que o problema da integração e da coesão social não pode ser entregue exclusivamente à empresa, que atua, evidentemente, pela lógica da competitividade e do mercado. Esse papel é essencialmente do Estado, o lócus da política, a quem cabe minimamente primar pelo interesse coletivo e pela paz e bem estar social. Nesse campo, todavia, uma vez retraída a participação política dos trabalhadores e uma vez retraídos os movimentos de esquerda no mundo, entra em cheque o poder do Estado para regulamentar a atividade produtiva e o seu papel social. No caso do Estado brasileiro, como discute Mattoso (1997, p.39), sua adequação subordinada às condições da nova ordem ditada pelos agentes financeiros internacionais acelerou o processo de “desestruturação e de redução de sua capacidade de planejamento, financiamento, fiscalização, apoio à competitividade e à distribuição de renda".

A retração dos direitos do trabalho é produto, também, de pressão empresarial não apenas para que os governos adotem políticas neoliberais de desregulamentação dos mercados, mas também para um maior afrouxamento de seus controles e de sua função fiscalizadora. É nesse sentido que boa parcela do crescimento da informalidade e da precariedade do trabalho dos anos 90 pode ser explicada pela redução e ou evasão, por parte das empresas, do cumprimento dos encargos trabalhistas e sociais, e isso, no Brasil, em muito se deve aos baixos custos da ilegalidade. Por esse critério, no cálculo racional dos empresários, vale a pena sonegar e ludibriar, porque os custos de uma eventual descoberta e punição são compensados pelos ganhos decorrentes da sonegação. Em outras palavras, quero dizer que as recentes estratégias de acumulação do capital se beneficiam, também, da tolerância e da falta de controle do Estado para expandir e recriar diversas modalidades de operação não-regularizada de suas atividades, reiterando uma tendência secular de burla ao ordenamento jurídico, prejudicial não apenas aos trabalhadores informais, mas a todo o conjunto da sociedade, posto que o Estado tem não apenas a sua base tributária reduzida, mas também a sua própria capacidade de regulamentar a economia (Portes et al, 1989; DIEESE, 1997; Silva, 2003).

Se, de fato, no Brasil, a terceirização da economia permitiu a afluência de uma fração minúscula de profissionais qualificados oriundos dos estratos médios (Silva, 2003), grande parte da nova informalidade, e sobre a qual se debruça o debate contemporâneo, provém de um contingente majoritário de trabalhadores advindo de grupos sociais pauperizados, sobretudo por conta da ausência de qualificação e recursos, e que se insere em condições de trabalho das mais precárias, configurando, nas palavras desse mesmo autor, "o nicho dos recursos de sobrevivência de um exército de reserva estagnado em expansão com perspectivas cada vez mais reduzidas de reintegração econômica" (Silva, 2003, p.170). Vejamos, então, que categorias de trabalhadores constituem essa informalidade e como ela se distribui.

\section{AINDA A VELHA DUALIDADE: a apreensão empírica da informalidade}

Já comentamos sobre as dificuldades encontradas pelos estudiosos na tarefa de elaboração de um conceito para a informalidade, tendo em conta o atual contexto de complexificação das redes da atividade econômica e das formas de inserção dos trabalhadores no processo produtivo. Portes et al (1989) argumentam sobre a importância de entendermos a economia informal a partir do processo 
histórico de sua constituição em cada contexto específico. Por outro lado, a economia informal não pode ser considerada um eufemismo para a pobreza, devido à sua elevada heterogeneidade: há muito dinamismo na economia informal e ela é geradora de elevado nível de renda para muitos empreendedores informais. Todavia, a noção de pobreza não pode ser entendida apenas pelo critério de renda (ou insuficiência de renda), pois ela também está relacionada ao consumo ou ao acesso a serviços, como qualidade da moradia, acesso à educação, políticas de saúde coletiva, enfim, à noção de direitos e de cidadania. Esses aspectos remetem às escolhas políticas de uma sociedade $\mathrm{e}$ aos mecanismos que ela socialmente engendra para distribuir sua riqueza. E esse é essencialmente o campo do conflito político de classe. ${ }^{8}$

Nas seções iniciais deste artigo, buscou-se trazerà tona as características estruturais da expansão do capitalismo no Brasil, como forma de destacar um elemento de peso para o entendimento da informalidade que, em nossa realidade, sim, andou muito de mãos dadas com a questão da pobreza: esse elemento foi o baixo nível (ou abrangência) do assalariamento (pelas razões ali aventadas) e de regulação da atividade econômica. No entanto, esse assalariamento foi não apenas restrito como também se realizou sob um padrão muito baixo de distribuição de renda (salários e welfare state).É por isso que as noções de formal e informal perdem um pouco o sentido quando o foco de análise é a pobreza ou a distribuição de renda, ainda que o informal seja muito fortemente sinônimo de pobreza urbana para uma vasta camada de indivíduos que não tiveram acesso à educação. Daí Silva falar da importância do aspecto jurídico-institucional no entendimento da informalidade no país e da importância de se definir o foco de análise, de forma a se tomar em consideração "as diferentes dimensões da vida econômica que põem em questão diferentes categorias de trabalhadores"(1996, p.28).

No campo especificamente aqui abordado, o

${ }^{8}$ Nas sociedades capitalistas de tradição democrática, há dois grandes mecanismos centrais de distribuição de ren-

da: os salários e os serviços públicos (welfare state). Quan-

to mais abertos à participação política das massas traba-

lhadoras funcionarem esses dois mecanismos, menos

desigualmente será distribuída a riqueza. da inserção dos indivíduos na atividade produtiva, isso significa que a noção de trabalho informal é muito fortemente pensada como contraponto ao ordenamento que regulou as relações de trabalho e a seguridade social no país. O paradigma dominante, inclusive aquele que fundamenta a produção de informações estatísticas que intentam gerar evidências empíricas, é aquele que compreende a informalidade pelo método da negação: é informal o que não é regulado "pelas instituições da sociedade em um ambiente legal e social no qual atividades similares são reguladas" (Portes et al., 1989). O contraponto é, portanto, no Brasil, o leque de direitos que a CLT assegura, não apenas no campo individual, como limite à jornada, salário mínimo, direito a férias e ao descanso remunerado, $13^{\circ}$ salário, entre outros, mas, sobretudo, no campo da representação coletiva, que assegura que os termos do trabalho sejam acordados politicamente entre patrões e trabalhadores, não submetidos à livre negociação individual cujo parâmetro exclusivo é o mercado. Por outro lado, como já discutido, foi centralmente pela via do trabalho formal que o Estado brasileiro assegurou políticas de seguridade social.

Em termos operacionais, o desafio de conceituar e categorizar o trabalho informal se torna tanto maior porque os novos e diversificados arranjos produtivos tornam ainda mais complexas as interconexões entre o formal e o informal, $\mathrm{e}$ isso quase põe por terra as abordagens dualistas. Essa confusão afeta, como argumenta Vianna (2006), a própria produção das estatísticas oficiais que procuram evidenciar as transformações contemporâneas de um capitalismo globalizado. A heterogeneidade e a mutabilidade das situações de trabalho desafiam a construção de instrumentos adequados à apreensão das próprias mudanças no mundo do trabalho, e, ainda que essa apreensão seja adequada, sua produção empírica será sempre um retrato parcial da realidade e embute, naturalmente, as concepções dominantes. ${ }^{9}$

\footnotetext{
${ }^{9}$ No início dos anos de 1990, a PNAD - Pesquisa Nacional por Amostra de Domicílios ampliou as questões de seu questionário como forma de melhor apreender as transformações no mundo do trabalho, relacionadas à temática da informalidade, mas essa revisão não modificou o caráter de dualidade subjacente ao conceito (Vianna, 2006).
} 
Cabe, portanto, ao pesquisador especificar que variáveis e categorias são as mais adequadas para responder aos seus objetivos de pesquisa. Com o fim de operacionalizar empiricamente o conceito aqui discutido e apresentar dados agregados que nos deem uma dimensão da informalidade e do perfil de seus trabalhadores no Brasil, considerase como informal, conforme sua agregação por posição da ocupação, os seguintes grupos de trabalhadores: empregados sem carteira, doméstico sem carteira, conta própria, trabalhadores na produção para o próprio consumo, trabalhadores na construção para o próprio uso e os não-remunerados.

Os trabalhadores informais representavam, em 2006, 55\% dos trabalhadores ocupados, sendo sua grande maioria, $57 \%$, constituída de mulheres. Elas, por sua vez, estavam inseridas em menor proporção (43\%) do que os homens (46\%) no mercado de trabalho formal, confirmando, uma vez mais, a tendência de inserção das mulheres no mercado de trabalho em condições mais precárias que a dos homens. Se tomarmos a proporção dos informais sobre a População Economicamente Ativa (PEA) e agregarmos a parcela dos desocupados, teremos que a informalidade salta para assustadores 59\%. Em outras palavras, praticamente $60 \%$ da população economicamente ativa no país não usufrui dos direitos legais relacionados ao trabalho, realidade que vem se juntar à elevada proporção dos que não contribuem para a previdência social - 89\% entre os informais -, o que agrava ainda mais a condição de instabilidade e insegurança econômica e social dos brasileiros. Do total de trabalhadores ocupados, apenas $49 \%$ contribuem para a previdência. As Tabelas 1,2 e 3 resumem as estatísticas.

Se olharmos para a distribuição dos trabalhadores informais por sua posição na ocupação (Tabela 4), ganham
Tabela 1 - Brasil: distribuição dos ocupados por sexo

\begin{tabular}{|c|c|c|c|}
\hline & Ocupados & Homens & Mulheres \\
\hline Formais & 45 & 46 & 43 \\
\hline Informais & 55 & 54 & 57 \\
\hline Total de Ocupados ${ }^{(1)}$ & 100 & 58 & 42 \\
\hline
\end{tabular}

Fonte: IBGE/PNAD 2006.

Trabalhadores ocupados de 10 ou mais anos na semana de referência ${ }^{(1)}$ Exclusive empregadores

Tabela 2 - Brasil: distribuição da PEA por sexo em 2006

\section{$\%$}

\begin{tabular}{l|c|c|c}
\hline & Total & Homens & Mulheres \\
\hline PEA & 100 & 100 & 100 \\
\hline Ocupados $^{(1)}$ & 92 & 94 & 89 \\
\hline \multicolumn{1}{c|}{ formais } & 41 & 43 & 38 \\
\hline informais & 51 & 50 & 51 \\
\hline Desocupados & 8 & 6 & 11 \\
\hline Informais + Desocupados & 59 & 57 & 62
\end{tabular}

Fonte: IBGE/PNAD 2006.

Trabalhadores ocupados de 10 ou mais anos na semana de referência ${ }^{(1)}$ Inclusive empregadores

Tabela 3 - Brasil: ocupados e informais por contribuição à Previdência em 2006

\begin{tabular}{l|c|c}
\hline & $\begin{array}{c}\text { Contribui para } \\
\text { Previdência }\end{array}$ & $\begin{array}{c}\text { Não contribui } \\
\text { para } \\
\text { Previdência }\end{array}$ \\
\hline Informais & 11 & 89 \\
\hline Total de ocupados ${ }^{(1)}$ & 49 & 51 \\
\hline Fonte: IBGE/PNAD 2006. \\
Trabalhadores ocupados de 10 ou mais anos na semana de referência \\
(1) Inclusive empregadores
\end{tabular}

destaque os empregados sem carteira (32\%) e os trabalhadores por conta própria (38\%). Eles representavam $18 \%$ e $21 \%$, respectivamente, do total de ocupados em 2006, justamente, segundo o que reclama a literatura, as principais formas de inserção para onde se deslocaram os desempregados após a reestruturação da economia. 
A última pesquisa do IBGE sobre a informalidade urbana no país, realizada em 2003, parece corroborar tal argumento. ${ }^{10}$ Lá se constata que $88 \%$ das unidades produtivas do setor informal eram formadas por trabalhadores por conta própria, sendo que a sua mais absoluta maioria, 93\%, não possuía constituição jurídica e era composta (80\%) por apenas um trabalhador. Em dez anos, de 1993 a 2003, registrou-se um crescimento de 11\% no número desses microempreendimentos, boa parte deles (32\%) concentrado no comércio e nos serviços de reparação e outra parcela considerável (18\%) na construção civil.

Voltando à nossa tabela da distribuição dos informais por posição na ocupação, é também digno de nota a proporção (11\%) dos não-remunerados dentre os trabalhadores informais, representando 6\% dos trabalhadores ocupados em 2006 (essa proporção chegou a $9 \%$ em 1996). Eles normalmente se concentram nas atividades realizadas por membros da família ou amigos, majoritariamente mulheres, e representam $5,54 \%$ da força de trabalho sem rendimentos monetários no total da PEA. A Tabela não mostra, mas no que respeita a outra categoria das mais tradicionais do trabalho informal, a dos trabalhadores domésticos, em sua mais absoluta maioria representada pelas mulheres, $73 \%$ não têm registro em carteira, o que nos dá uma dimensão do quanto essa categoria de trabalhadores permanece alijada da cobertura de direitos, mesmo tendo um estatuto diferenciado, e ainda mais flexível, que o dos demais trabalhadores privados.

Um elemento essencial para abrir oportunidade de inserção menos precária dos trabalhadores na atividade produtiva, seja no mercado de trabalho formal seja no informal, é o nível educacional do trabalhador. Há um consenso universal sobre o fato de que a educação atua como um fator que influi no status da ocupação, muito embora, com a reestruturação do capital no final do milênio, seja forte a tendência a um desacoplamento entre a estrutura educacional e a estrutura ocupacional, com

${ }^{10}$ IBGE, Diretoria de Pesquisas, Coordenação de Trabalho e Rendimento, Economia Informal Urbana 2003. Disponível em: <www.ibge.gov.br>. a população mais educada, principalmente a mais jovem, enfrentando oportunidades de emprego deterioradas no mercado de trabalho (Hasenbalg; Silva 2003; Fantasia; Voss, 2004). De fato, os dados da PNAD 2006 confirmam que mais anos de estudo podem significar uma melhor inserção no mercado de trabalho: o grosso das pessoas ocupadas no mercado de trabalho informal possui baixo nível de instrução. Em números mais específicos, a Tabela 5 nos mostra que $42 \%$ dos trabalhadores informais possuem até 4 anos de estudos, sendo que praticamente $30 \%$ deles sequer chegaram a concluir o ensino fundamental, estando no que hoje comumente se considera como numa situação de analfabetismo funcional. As proporções dos trabalhadores com até 4 anos de estudo e abaixo desse nível entre os formais é de $16 \%$ e 9\%, respectivamente. Na subida da escala, pode-se verificar que uma proporção significativa dos trabalhadores formais (40\%) possui entre 9 e 11 anos de estudos ou o $2^{\circ}$ grau incompleto. Em sua absoluta maioria, $60 \%$, os trabalhadores informais sequer concluíram o primeiro grau ou o antigo ginasial. A diferença é ainda mais considerável entre os que possuem mais de 12 anos de estudo. Apenas 6\% dos informais se encontram nesse nível de instrução contra 19\% entre os formais.

Pressionado pelas demandas de um padrão de competitividade internacional, o Brasil se depara, nos anos 90, com o desafio de elevar o

Tabela 5 - Brasil: distribuição dos trabalhadores ocupados por grau de instrução em $2006 \quad \%$

\begin{tabular}{l|c|c}
\hline Grau de Instrução & Formais & Informais \\
\hline Sem instrução e menos de 1 ano & 3 & 13 \\
\hline Até 3 anos & 6 & 15 \\
\hline Fundamental completo & 8 & 14 \\
\hline 1o grau incompleto & 11 & 18 \\
\hline 1o grau completo & 10 & 10 \\
\hline 2o grau incompleto & 40 & 22 \\
\hline 2o grau completo & 3 & 1 \\
\hline Mais de 12 anos de estudo & 19 & 6 \\
\hline Sem declaração & 0,5 & $0,5 \%$ \\
\hline Total & 100 & 100 \\
\hline $\begin{array}{l}\text { Fonte: IBGE/PNAD 2006. } \\
\text { Trabalhadores Ocupados de 10 ou mais anos na semana de } \\
\text { referência }\end{array}$ &
\end{tabular}


baixíssimo nível de instrução de sua força de trabalho, produto da também baixíssima prioridade da educação básica no modelo de desenvolvimento por substituição de importações. Estamos, portanto, procurando enfrentar esse desafio com um atraso de pelo menos 50 anos em relação à trajetória de outras sociedades mais desenvolvidas. Destarte, é sabido que, nos últimos anos, tem se registrado uma elevação dos anos de estudos da força de trabalho, reflexo dos esforços das políticas públicas no sentido de reduzir o enorme déficit educacional do país. No entanto, a melhora educacional da força de trabalho também vem se dando por outra via que, de uma perspectiva macrossocial, passa a exigir do Estado políticas consistentes e coordenadas de qualificação e seguro desemprego. No campo dos empregos formais, com a reestruturação produtiva da economia, a elevação dos anos de estudo da força de trabalho fortemente traduziu uma sólida tendência de as empresas estabelecerem como um de seus critérios básicos de contratação a exigência de, pelo menos, o $1^{\circ}$ grau de instrução (8 anos de estudo), o que, em muitos casos, implicou a dispensa de trabalhadores de meia idade e baixa escolarização, que dificilmente retornam a exercer suas qualificações num emprego formal (Cardoso; Comin; Guimarães, 2006; Chahad, 2006). Sendo cada vez mais seletivos os critérios de contratação das empresas (em muitos segmentos a exigência mínima passa a ser o $2^{\circ}$ grau completo), maior ainda passa a ser o exército industrial de reserva constituído de trabalhadores semi ou não-qualificados, que buscam meios de sobrevivência no trabalho informal. Ainda que a economia retome o ritmo de crescimento alcançado nas décadas de $1960 \mathrm{e}$ 1970, e ainda que seja consistente a ampliação dos empregos formais, como vem sendo registrado desde 2003 (IPEA, 2007), haverá um considerável contingente de trabalhadores que, a menos que seja beneficiado com políticas eduatividade principal. cacionais e de qualificação, jamais será incorporado pela economia formal.

No que respeita à renda, podemos visualizar, na Tabela 6, que consideráveis 65\% dos trabalhadores informais auferem até um salário mínimo de rendimento mensal; essa proporção entre os formais é de $24 \%$. Boa parcela dos trabalhadores formais, $40 \%$, está concentrada na faixa de salários que vai de um a dois salários mínimos. A proporção dos trabalhadores informais nessa faixa de salários é de apenas $21 \%$. Todavia, é ainda mais significativo que $25 \%$ dos homens e $40 \%$ das mulheres, dentre os trabalhadores informais, se encontrem na faixa de rendimentos de até meio salário mínimo. As estatísticas não nos falam da riqueza das particularidades, mas, provavelmente, esse significativo contingente de trabalhadores compõe os estratos de pobreza e indigência que caracterizam as modalidades de atividade informal cotadas como condição de pura alternativa de sobrevivência, onde se encontra a categoria dos trabalhadores de rua, objeto da etapa da análise qualitativa desta pesquisa. No momento, as estatísticas apenas nos mostram que a categoria dos trabalhadores por conta própria concentra o agregado de trabalhadores informais nas duas pontas da escala salarial: $47 \%$ dos que auferem até meio salário mínimo pertencem a essa categoria. Subindo na escala, $68 \%$ dos informais que auferem de 2 a $3 \mathrm{SM}$ e $71 \%$ dos que recebem de 3 a $5 \mathrm{SM}$ também pertencem ao agregado dos trabalhadores por conta própria. Esses números nos dizem da

Tabela 6 - Brasil: Distribuição dos ocupados por faixa de salário e sexo

\begin{tabular}{|c|c|c|c|c|c|c|}
\hline \multirow{2}{*}{$\begin{array}{l}\text { Faixa de renda em } \\
\text { Salário Mínimo }^{(1)}\end{array}$} & \multicolumn{3}{|c|}{ Formais } & \multicolumn{3}{|c|}{ Informais } \\
\hline & Total & Homem & Mulher & Total & Homem & Mulher \\
\hline Até meio SM & 1 & 1 & 1 & 31 & 25 & 40 \\
\hline Mais de meio a $1 \mathrm{SM}$ & 23 & 18 & 31 & 34 & 33 & 35 \\
\hline Mais de 1 a 2 SM & 40 & 41 & 40 & 21 & 24 & 16 \\
\hline Mais de 2 a 3 SM & 13 & 15 & 11 & 6 & 8 & 4 \\
\hline Mais de 3 a 5 SM & 12 & 13 & 10 & 5 & 6 & 3 \\
\hline Mais de 5 a $10 \mathrm{SM}$ & 2 & 2 & 2 & 1 & 1 & 0 \\
\hline Mais de 10 a $20 \mathrm{SM}$ & 3 & 3 & 2 & 1 & 1 & 0 \\
\hline Mais de 20 até 50 SM & 1 & 1 & 0 & 0 & 0 & 0 \\
\hline
\end{tabular}

Fonte: IBGE/PNAD 2006. Ocupados de 10 ou mais anos na semana de referência na

Valor do Salário Mínimo Oficial: R\$ 415,00

Exclusive empregadores 
importância desses trabalhadores na estatística da informalidade e da enorme heterogeneidade de suas situações de renda e de trabalho. As Tabelas 6 e 7 apresentam as estatísticas. informalidade e ela é, por definição, o reino do nãodireito, o que presenciamos, no campo da sociabilidade, é uma degradação quase que generalizada da segurança dos indivíduos; uma insegurança vivida no emprego, na renda, na seguridade social, na representação do trabalho (Mattoso, 1996), mas também na capacidade de planejamento, na possibilidade de garantir a refeição do dia, no porvir.

\section{À GUISA DE CON- CLUSÃO: mais regulação, mais Estado}

A concentração dos trabalhadores informais nas faixas de salário mais baixas, de meio até 1 salário mínimo, parece confirmar aquela velha proposição de que o nível educacional tem efeito sobre o padrão de rendimento ou a forma de inserção do indivíduo no mercado de trabalho. Parece confirmar, também, o argumento de que a informalidade anda de mãos dadas com a pobreza no nosso país, realidade que se agrava pela ausência ou insuficiência do Estado no campo do provimento dos serviços públicos e sociais. Ainda que sejam restritos o assalariamento e o baixo o padrão de renda da força de trabalho, produto das desigualdades estruturais já discutidas, esses números nos dizem da importância do vínculo formal de trabalho não apenas no campo dos direitos individuais, mas no da capacidade política de reversão daquelas desigualdades. Eles corroboram, como fizeram outras pesquisas sobre a mesma realidade em regiões específicas do país (Jakobsen et al, 2000; Filgueiras et al, 2004), o grau de precariedade da inserção produtiva de um número crescente de trabalhadores brasileiros.

Se a noção de flexibilidade que acompanha as mudanças no regime de emprego tradicional vem incorporando, cada vez mais, um sentido de
No momento em que concluo este texto, as celebrações por parte do poder público, no Brasil, de uma retomada, a partir de 1999 e, sobretudo, depois de 2002, dos empregos com carteira, ainda que positivas, mais se assemelham a retóricas ante o enorme déficit nos números da inserção econômica e social historicamente registrados no país. Se, de fato, a informalidade vem se retraindo (Brasil, 2008; IPEA,2007; Pochmann, 2006; Chahad, 2006), há uma forte dependência da solidez do crescimento econômico. Mas esse crescimento, como consequência do atual estágio tecnológico e das estratégias de organizar o processo produtivo, parece não guardar mais a forte relação positiva com o nível de emprego que registrou em décadas passadas. Por um lado, caberia distinguir, como sugere Chahad (2006), em que medida aquela retomada se deve a uma maior formalização da economia, devido às políticas de incentivo, inclusive decorrentes de maior flexibilização dos direitos do trabalho, e de fiscalização do Estado; e em que megos. Por outro, é importante ter em mente a tendência acima comentada: os atuais parâmetros de contratação das empresas deixam de fora, sem sedida ela provém de aumento genuíno dos empre- 
quer ter a possibilidade de concorrer, um vasto exército industrial de trabalhadores semi ou nãoqualificados, esses ainda mais dependentes de políticas públicas. Temos, assim, que crescimento econômico, per se, não é sinônimo de mais emprego formal ou de distribuição de renda. ${ }^{11}$

Voltando à nossa reflexão inicial, a diminuta redução da informalidade (o IPEA, na análise dos números da PNAD, registrou uma queda de 2,37 pontos percentuais entre 2002 e 2006) não decorre de efetivas mudanças estruturais no regime de relações de trabalho, na estrutura fundiária, ou mesmo no regime tributário do país. Ao contrário, a política de estabilização da economia vem se pautando ainda mais contundentemente no fortalecimento dos interesses do capital financeiro e do capital agroexportador de bens primários: o primeiro pouco comprometido com a produção e a geração de empregos; o segundo, ora apoiado na mecanização ora na superexploração do trabalho, continua a reproduzir as formas arcaicas de relações de produção ainda prevalecentes no campo (o caso do etanol é emblemático). É nesse sentido que a retomada do crescimento e uma possível ampliação do emprego regulado muito dificilmente ou apenas de forma bastante limitada podem contribuir para uma efetiva diminuição do vergonhoso quadro de desigualdade social (e a informalidade é a sua face mais perversa) e dos sofrimentos a que seus trabalhadores se submetem.

A desocupação, o subemprego, o trabalho informal, o emprego regulamentado, mas de baixíssimos salários e poder de barganha, são problemas centrais na sociedade brasileira e estão no âmago de suas profundas desigualdades estrutu-

11 De outra perspectiva, argumenta no mesmo sentido: segundo sua análise, entre 1992 e 2005, o crescimento do PIB real foi de $44 \%$, superior ao crescimento da PEA $(32 \%)$, ao total do pessoal ocupado $(25,6 \%)$ e muito acima do crescimento do emprego formal $(17,8 \%)$. Em suas palavras: "o maior crescimento da PEA, relativamente ao total de pessoal ocupado, explica por que tem havido crescimento contínuo do desemprego aberto e da informalidade do trabalho. O maior crescimento do total de pessoal ocupado, por sua vez, do que o emprego formal é indicativo que os empregos protegidos pela legislação trabalhista e previdenciária, os chamados "bons" empregos, tem crescido bem menos do que as ocupações informais, precárias, atípicas, ou desprotegidas" (Chahad, 2006, p.47). rais, marca de um padrão de acumulação concentrador de renda e perpetuador da pobreza. Enfrentar tais problemas requer mudanças profundas naquelas desigualdades estruturais, e isso necessariamente passa pelo embate político do conflito de classe, adverso, nos últimos governos, para os trabalhadores. ${ }^{12}$ Nesse embate cabe ressaltar a questão do papel do Estado, de sua responsabilidade pela condução dos destinos da sociedade, sobretudo no que remete à institucionalização de mecanismos democráticos que possibilitem que o próprio conflito se dê de forma menos desequilibrada. E aqui cabe destacar a importância da regulamentação do mercado de trabalho e das políticas públicas no campo do planejamento econômico e da cidadania. Em outras palavras, a informalidade é um problema social, portanto de interesse público. Ela demanda do Estado políticas que primem por um sistema de distribuição de renda mais equitativo, apoiado no princípio da universalização de direitos e por intervenções que limitem a ganância das empresas, uma vez que delas provém grande parte das mudanças que ora prescindem do trabalho, ora o explora de forma abjeta. O fortalecimento dos movimentos sociais e do trabalho tem relação direta com o fortalecimento desse poder de intervenção.

(Recebido para publicação em janeiro de 2009) (Aceito em maio de 2009)

\section{REFERÊNCIAS}

ANTUNES, Ricardo. Os sentidos do trabalho: ensaio sobre a afirmação e a negação do trabalho. São Paulo: Boitempo, 2000.

BOITO Jr., Armando. Política neoliberal e sindicalismo no Brasil. São Paulo: Ed. Xamã, 1999.

BOYER, Robert. Capital-labour relations in OCDE countries: from the fordista golden age to contrasted national trajectories. In: CAPITAL, the State and Labour: a global perspective. Tokyo: United Nations University Press, 1995.

${ }^{12}$ Para uma análise contundente de como se tem configurado as forças políticas no Brasil após a avalanche de medidas neoliberais das últimas duas décadas ver, por exemplo: Oliveira (2005), Cardoso (2003), Boito Jr (1999), Mattoso (1997). 
BRASIL. Governo Federal. Emprego formal já ultrapassa 1,5 milhão de vagas em 2008. Disponível em: www.brasil.gov.br/noticias/em_questao/.questao/eq689/

CACCIAMALI, Maria C. "Globalisação e processo de infomalidade. Economia e Sociedade. Campina. SP. UNICAMP. (14). ppp153-174. junho. 2000.

Setor informal urbano e formas de participação $\overline{n a ~ p r o d u c ̧ a ̃ o . ~ S a ̃ o ~ P a u l o: ~ I P E / U S, ~} 1983$.

Globalização e processo de informalidade. In: ENCONTRO NACIONAL DE ECONOMIA, 1999, Belém. Anais... Belém: ANPEC, 1999. v.3. p.2059-2074.

CARDOSO, Adalberto; COMIN, Alvaro A.; GUIMARÃES, Nadya. Os deserdados da indústria: reestruturação produtiva e trajetórias intersetoriais de trabalhadores demitidos da indústria brasileira. In: GUIMARÃES. Nadya HIRATA, Helena. Desemprego: trajetórias, identidades, mobilizações. São Paulo: Senac, 2006.

CARDOSO, Adalberto M. A década neoliberal e a crise dos sindicatos no Brasil. São Paulo: Boitempo, 2003.

CASTEL. Robert. As metamorfoses da questão social. Petrópoles: Vozes, 1998.

CASTELLS, Manuel. A sociedade em rede. 5.ed. São Paulo: Paz e Terra, 2001. v.1.

CHAHAD, José. O emprego formal no Brasil entre 1992 2006: comportamento, tendências atuais e suas causas explicativas. In: MACAMBIRA, J. O mercado de trabalho formal no Brasil. Fortaleza: Imprensa Universitária, 2006. p.43-68.

COSTA, Carlos R. Estrutura de classes, condições de vida e oportunidades de mobilidade social no Brasil. In HASENBALG, Carlos; SILVA, Nelson do Valle. Origens e destinos: desigualdades sociais ao longo da vida. Rio de Janeiro: Topbooks, 2003. p.381-425.

COSTA, Márcia da S. Despotismo de mercado: medo do desemprego e relações de trabalho. João Pessoa: Ed. Universidade Federal da Paraíba, 2006.

. O sistema de relações de trabalho no Brasil. Alguns traços históricos e sua precarização atual. Revista Brasileira de Ciências Sociais, São Paulo, v.20, n.59, p.111 132, 2005.

DEDECA, Claudio S. Racionalização econômica e heterogeneidade nas relações e nos mercados de trabalho no capitalismo avançado. In: OLIVEIRA, Carlos A. MATTOSO, Jorge E. (Org.). Crise e Trabalho no Brasil: modernidade ou volta ao passado. 2.ed. Campinas,SP Scritta, 1997.

DIEESE. Pesquisa No 12. Encargos Sociais no Brasil: conceito, magnitude e reflexos no emprego. DIEESE, São \& Paulo, agosto de 1997

FANTASIA, Rick; VOSS, Kim. Hard work: remaking the american labor movement. Berkeley,USA: University of California Press,2004.

O UFBA, Salvador, v.17. maio/ago., p.211-229, 2004

FRIGOTTO, Gaudêncio. Juventude, trabalho e educação no Brasil: perplexidades, desafios e perspectivas. In NOVAES, R.; VANNUCHI, P. Juventude e sociedade: trabalho educação, cultura e participação. São Paulo: Fundação Perseu Ảbramo, 2004. p.180-216.

FURTADO, Celso. O capitalismo global. São Paulo: Paz e Terra, 1998.
HASEMBALG, Carlos; SILVA, Nelson do Valle. Origens e destinos: desigualdades sociais ao longo da vida. Rio de Janeiro: Topbooks, 2003.

HENRIQUES, Ricardo (Ed.) Desigualdade e pobreza no Brasil. Rio de Janeiro: IPEA, 2000.

IPEA/PNAD. Primeiras análises: demografia, educação, trabalho, previdência, desigualdade de renda e pobreza 2006. Disponível em: www.ipea.gov.br. Acesso em: 2007.

JAKOBSEN, Kjeld et al. Mapa do trabalho informal: perfil socioeconômico dos trabalhadores informais na cidade de São Paulo. Fundação Perseu Abramo, 2000.

KOVARICK, Lucio. Capitalismo e marginalidade na América Latina. Rio de Janeiro: Paz e Terra, 1975.

KREIN, J. Dari. Reforma no sistema de relações de trabalho no Brasil. In: . Emprego e desenvolvimento tecnológico. São Paulo: Dieese/Cesit/Unicamp, 1999.

LARANJEIRA, Sônia. M.G. Há lugar para o sindicalismo na sociedade pós-industrial? Aspectos do debate internacional. São Paulo em Perspectiva, São Paulo, v.12, n.1, jan./mar., 1998.

MATTOSO, Jorge. A desordem do trabalho. São Paulo: Scritta, 1996.

Emprego e concorrência desregulada: incertezas e desafios. In: OLIVEIRA, Carlos A.: MATTOSO, Jorge E. (Org.) Crise e trabalho no Brasil: modernidade ou volta ao passado. 2.ed. Campinas,SP: Scritta, 1997.

O Brasil desempregado. São Paulo: Ed. Perseu Abramo, 1999.

OLIVEIRA, Francisco de. Crítica à razão dualista: o ornitorrinco. São Paulo. Boitempo. 2003.

. Elegia para uma re(li)gião. Sudene, Nordeste: planejamento e conflito de classe. São Paulo: Paz e Terra, 1977.

POLANYI, Karl. A grande transformação. Rio de Janeiro: Ed. Campus, 1980.

POCHMANN, Márcio. Trabalho sob fogo cruzado. São Paulo: Contexto, 2002.

. Mapa recente da dinâmica do emprego formal no Brasil. In. MACAMBIRA, J. (Org.) O mercado de trabalho formal no Brasil. Fortaleza: Imprensa Universitária, 2006. p.23-86.

PORTES, Alejandro; CASTELLS, Manuel. World underneath: the origins, dynamics, and effects of the informal economy. In: ; ; ; BNTON, Lauren (Org). The informal economy. Baltimore and London: The John Hopkins University Press, 1989. p.11-34.

QUADROS, Waldir. Classes sociais e desemprego no Brasil dos anos 1990. Economia e Sociedade, Campinas,SP, v.12, n.1 p.109-135, jan./jun., 2003.

RAMOS, Marise; FRIGOTTO, Gaudêncio; CIAVATTA, Maria. A política de educação profissional no governo Lula: um percurso histórico controvertido. Educação e Sociedade, Campinas,SP, v. 26, p.1087-1113, 2005.

RIBEIRO, Darcy. O povo brasileiro. São Paulo: Companhia das Letras, 2006.

SILVA, Luiz Machado da. Mercado de trabalho ontem e hoje: informalidade e empregabilidade como categorias de entendimento. In: SANTANA, Marco Aurélio; RAMALHO, José Ricardo (Org.) Além da fábrica: sindicatos, trabalhadores e a nova questão social. São Paulo: Boitempo, 2003

Informalização: mas o que se quer dizer com isto? Monitor Público, Rio de Janeiro, v.3, n.11, p.1-51, out./dez., 1996. 
SABADINI, Maurício S.; NAKATANI, Paulo. THEODORO, Mário. A questão do desenvolvimento: uma Desestruturação e informalidade do mercado de trabalho releitura. In: RAMALHO, Jether; ARROCHELLAS, Maria no Brasil. Revista Venezolana de Conyuntura, Caracas, H. Desenvolvimento, subsistência e trabalho informal no n.2, jul./dez., 2002.

Brasil. São Paulo: Cortez, 2004. p.15-44.

SANSONE, Livio. Jovens e oportunidades: as mudanças na década de 1990: variações por cor e classe. In: HASENBALG, Carlos; SILVA, Nelson do Valle. Origens e destinos: desigualdades sociais ao longo da vida. Rio de Janeiro: Topbooks, 2003. p.245-280.

As caractrerísticas do mercado de trabalho e as origen $s$ da informalidade no Brasil. In: RAMALHO, Jether ARROCHELLAS, Maria H. Desenvolvimento, subsistência e trabalho informal no Brasil. São Paulo: Cortez, 2004. p.77-116.

SANTANA, Marco A.; RAMALHO, José R. Trabalhadores, sindicatos e a nova questão social. In:

(Org). Além da fábrica: sindicatos, trabalhadores è a nova questão social. São Paulo: Boitempo, 2003.

VIANNA, Márcia C. Segadas. A discussão histórica da informalidade: significados e formas de representação. 2006. Tese (Doutorado em Sociologia) - Instituto Universitário de Pesquisa do Rio de Janeiro, 2006 (Mimeo.)

SANTOS, Vanderlei Guilherme dos. Cidadania e justiç: a política social na ordem brasileira. Rio de Janeiro: Campus, 1979. 
INFORMAL LABOR: a basic structural problem in the understanding of inequalities in Brazilian society

\section{Márcia da Silva Costa}

This paper rescues the theoreticalconceptual debate that involves the theme the informality, in essence, that of dominance relationships that favored the capitalist accumulation in this country. Starting from the data of PNAD 2006, the distribution of the busy workforce is also analyzed. Who are the informal ones and how are they distributed? Which income and education profile do they have? These discoveries corroborate the analytical arguments that understand the informality as a basic structural problem in Brazilian society. Its growth asserts the historical picture of inequality and poverty that marked its development pattern. Even if the economy grows again, there will be a considerable contingent of workers that, unless benefitted with solid educational policies, will never have the possibility of being incorporated in the regulated economy.

KEYWORDS: informal labor, labor precariousness, inequality.
LE TRAVAIL INFORMEL: un problème structurel basique pour comprendre les inégalités dans la société brésilienne

\section{Márcia da Silva Costa}

Ce texte reprend le débat théorique et conceptuel à propos du thème de l'informalité en tant que tel, le débat sur les liens de domination qui ont favorisé l'accumulation du capital dans le pays. A partir des données du PNAD 2006, on y fait également une analyse de la distribution de la force de travail active. Qui sont ces informels et comment sont-ils répartis ? Quel est le profil de leurs revenus et de leur scolarisation ? Les résultats corroborent les arguments de l'analyse qui considèrent l'informalité comme un problème structurel de base dans la société brésilienne. Son augmentation confirme le cadre historique d'inégalité et de pauvreté qui a marqué son modèle de développement. Même si l'économie reprenait, il y aurait toujours un grand nombre de travailleurs qui, à moins d'être bénéficiaires de politiques éducatives solides, n’auraient jamais la possibilité d'être intégrés dans l'économie formelle.

Márcia da Silva Costa - Doutora em Sociologia pelo Instituto Universitário de Pesquisa do Rio de Janeiro IUPERJ. Professora e pesquisadora do Departamento de Administração da Universidade Federal da Paraíba e do Programa de Pós-Graduação em Administração da mesma Universidade, desenvolvendo pesquisas na área do trabalho e organizações. Suas mais recentes publicações, são: COSTA, M. S. Reestruturação Produtiva e Trabalho na Indústria Têxtil Brasileira. In: NEVES, Jorge Alexandre Barbosa; FERNANDES, Danielle Cireno; HELAL, Diogo Henrique (Org.). Educação, trabalho e desigualdade social. $1^{\text {a }}$ ed. Belo Horizonte: Editora Argvmentvn, 2008. COSTA, M. S. Relações de trabalho e regimes de emprego no Canadá e no Brasil: RAE Eletrônica, v. 6, n. 2, p. 1/16-29, 2007. COSTA, M. S.; MATIAS, Karla; GODIM, Cibelle. Mercado de trabalho em turismo e representação sindical: um estudo sobre o Sindicaturismo na Paraíba. GESTÃO. Org. Revista Eletrônica de Gestão Organizacional, v. 5, p. 241/6-256, 2007. COSTA, M. S. Labour relations and the 1990s employment regimes in Canada and Brasil. Just Labour, v. 9, p. 46/4-56, 2006. 